\title{
Epidemiology of hepatitis B in Tunisia: retrospective study in 198157 blood donors in military environment
}

\author{
MT Khoufi, A Mrabet, B Nsiri, MN Ebdelli, M Yedeas \\ From International Symposium HIV and Emerging Infectious Diseases 2014 \\ Marseille, France. 21-23 May 2013
}

\section{Introduction}

Hepatitis B is endemic in Tunisia. His prevalence was evaluated at $5.5 \%$ in 1990 . The aim of this study is to estimate the prevalence of this disease in the last years in Tunisia.

\section{Methods}

it was a retrospective study about all the blood donors in the Military Center of Blood Transfusion between 2000 and 2011.

The Ag HBs was systematic for every blood donation, by immuno-enzymatic reaction.

\section{Results}

In this period, 198157 blood donors were compiled. These donors were, for $95 \%$, young men, between 20 and 25 years, from all the parts of the country.

This study showed:

- A net decrease in prevalence of hepatitis B in 12 years: from $3.54 \%$ in 2000 to $0.8 \%$ in 2011.

- A regional disparity of this prevalence.

- No identification of a population at risk.

- The improvement of hygiene and the use of disposable syringes in hospitals can explain this decrease of the prevalence; HVB vaccination began in 1995 and didn't affect the sample of the study.

\section{Conclusion}

Hepatitis B is still a public health problem in Tunisia. Vaccination and better socio-economic condition will lead in short term to the decrease of the HVB prevalence, started since the 90's.

Published: 23 May 2014

General Direction of military health, Tunis, Tunisia
doi:10.1186/1471-2334-14-S2-P16

Cite this article as: Khoufi et al:: Epidemiology of hepatitis B in Tunisia: retrospective study in 198157 blood donors in military environment. BMC Infectious Diseases 2014 14(Suppl 2):P16.
Submit your next manuscript to BioMed Central and take full advantage of:

- Convenient online submission

- Thorough peer review

- No space constraints or color figure charges

- Immediate publication on acceptance

- Inclusion in PubMed, CAS, Scopus and Google Scholar

- Research which is freely available for redistribution 